\title{
MONOCLONAL ANTI-IDIOTYPE ANTIBODY TO HSV-1 NEUTRALIZING MONOCLONAL ANTIBODY: PRODUCTION AND CHARACTERIZATION
}

\author{
VEENITA S. DAR ${ }^{\dagger}$ AND PRADEEP SETH* \\ Virology Section, Department of Microbiology; All India Institute of Medical Sciences, Ansari Nagar, \\ New Delhi 110029, India \\ ${ }^{\dagger}$ Present affiliation: Hybridoma Laboratory, National Institute of Immunology, Shaheed Jeet Singh \\ Marg, New Delhi 110067, India.
}

\begin{abstract}
SUMMARY
This study is an attempt to produce and characterize murine monoclonal antibodies directed against the paratope of HSV-1 neutralizing monoclonal antibody. Monoclonal antibody 138 C5G10 which was neutralising and directed to $120 \mathrm{~K}$ antigen $\mathrm{gB}$ of HSV-1 was used as the idiotype. We were able to produce three Ab-2 monoclonal antibodies as characterized using immunofluorescence, ELISA and RIA. The findings of the present study suggest that two antiidiotypes $3 \mathrm{AiB} 3 \mathrm{E} 10$ and $3 \mathrm{AiB} 5 \mathrm{D} 10$ share the same unique fine specificity while $3 \mathrm{AiB} 3 \mathrm{C} 9$ has a different specificity on 138 C5G10 paratope. The utility of such 'surrogate' antigens in serological assays and modulation of immune response is discussed.
\end{abstract}

KEY WORDS Monoclonal antibody Anti-idiotype Herpes simplex virus

ABBREVIATIONS Ab-1: Antibody 1 Ab-2: Antibody 2 ELISA: Enzyme Linked Immunosorbant Assay RIA: Radio Immuno Assay NMS: Normal mouse serum

\section{INTRODUCTION}

Easy transmission from infected to susceptible hosts, latency, periodic reactivation of virus, and virus excretion associated with reactivation, are the chief characteristics of herpes simplex virus (HSV) infection. In view of the fact that immunity to a single major glycoprotein is adequate for neutralizing the virus, anti-idiotypes may function as surrogate antigen. Such an anti-idiotype would represent the internal image and mimic the antigens of the infectious virus to a susceptible host (Dreesman and Kennedy, 1985). Further, as a consequence of antigenic cross-reactivity between HSV-1 and HSV-2, serological detection of specific antibody against either of the serotypes of the herpes simplex virus is difficult. To circumvent this problem an anti-idiotype 'mirroring' the type-specific epitope universally present in all isolates of that particular serotype may be used to identify the infection.

* Correspondence to: Pradeep Seth MD, Virology Section, Department of Microbiology, All India Institute of Medical Sciences, Ansari Nagar, New Delhi 110029, India. 


\section{MATERIALS AND METHODS}

\section{Specificity of HSV hyperimmune sera raised in rabbits}

HSV-1 antigen was made in primary rabbit kidney cells (Lennette and Smith, 1979). This antigen was used for raising hyperimmune sera in rabbits of Haffkein strain. Titration of the hyperimmune sera was done by indirect hemagglutination (Bernstein and Stewart, 1971) with modifications (Seth et al., 1978). The relative reactivity of serum to HSV-1 and HSV-2 antigen was expressed as II/I index (Prakash and Seth, 1979). An index value of $<85$ was taken as an indication of HSV-1 specific response while a value of $>85$ was considered as HSV-2 specific antibody response (Seth et al, 1978).

\section{Immunization for producing anti-idiotypes}

Immunizing Idiotype:

Mouse monoclonal antibody 138 C5G10 (gifted by Dr P Rajamouli) which was raised and characterized in this laboratory was used for immunization. This antibody (Ab-1) reacted only with HSV-1 and not with HSV-2 infected vero cells in ELISA (Enzyme Linked Immunosorbant Assay) (Frame et al., 1984) and immunofluorescence. In radioimmuno precipitation assay (Pereira et al., 1980) it precipitated a 120 kilodalton glycoprotein corresponding to glycoprotein B of HSV-1 (gB-1) from infected vero cell lysates of HSV-1 only. It did not precipitate any protein from HSV-2 infected vero cell lysates. This antibody was tested for neutralising activity against AC strain (Gupta et al., 1972) of HSV-1 and 219 strain (Seth et al., 1974) HSV-2 by plaque reduction assay (Figueroa and Rawls., 1969). The results of this test showed that a plaque reduction of $50 \%$ was obtained for HSV-1 by this antibody using culture supernatant.

Immunization Schedule:

Six-week old inbred BALB/c mice were immunized according to the following schedule:

$\begin{array}{llc}\text { Dose } & \text { Route } & \text { Day } \\ 200 \mu \mathrm{g}(\mathrm{Ab}-1)+\mathrm{CFA} & \text { ip } & 0 \\ 100 \mu \mathrm{g}(\mathrm{Ab}-1) \text { in saline } & \text { sc } & \\ 300 \mu \mathrm{g}(\mathrm{Ab}-1)+\mathrm{CFA} & \text { ip } & 7 \\ 300 \mu \mathrm{g}(\mathrm{Ab}-1)+\mathrm{CFA} & \text { ip } & 14 \\ 300 \mu \mathrm{g}(\mathrm{AB}-1) \text { in saline } & \text { iv } & 24\end{array}$

Three days after the last dose the mice were sacrificed and the spleens collected aseptically for cell fusion (Kohler and Milstein, 1975).

\section{Cell Fusion}

The splenic lymphocytes were fused with SP2/0 myeloma cells in 1:1 ratio in the presence of polyethylene glycol 4000 . The cells were suspended in a selective medium consisting of RPMI 1640 supplemented with 10\% FCS, hypoxanthine, aminopterin and 
thymidine at a concentration of $5 \times 10^{5}$ spleen cells $/ \mathrm{ml}$. $1 \mathrm{ml}$ of this suspension was added to every well of 24 well tissue culture plate (Nunclon, USA) which already contained a feeder layer of mouse peritoneal macrophages at a concentration of $1 \times 10^{5}$ cells $/ \mathrm{ml}$. They were incubated at $37^{\circ} \mathrm{C}$ in presence of $5 \% \mathrm{CO}_{2}$. Supernatants from wells containing growing hybrids were screened for the presence of Ab-2 (antibody-2). Those found positive were cloned and further subcloned by limiting dilution to ensure monoclonality. They were screened at every stage.

\section{Screening for $A b-2$}

Immunofluorescence:

Surface immunofluorescence staining was done on cytocentrifuge smears (Thanavala et al., 1985a). Cells secreting Ab-2 clones were washed thrice in PBS, pH 7.4 in cold and cell concentration was adjusted to $1 \times 10^{6}$ cells $/ \mathrm{ml}$ in PBS, pH 7.4. Smears of $100 \mu$ l of the cell suspension were made by spinning in cytocentrifuge (Shandon, cytospin 2) at 700 $\mathrm{rpm}$ for $10 \mathrm{~min}$. The smears were air dried for $10 \mathrm{~min}$ at room temperature and fixed at $4^{\circ} \mathrm{C}$ for $20 \mathrm{~min}$ in a mixture of cold $95 \%$ ethanol and $5 \%$ acetic acid. For staining, the smears were incubated for $1 \mathrm{~h}$ at room temperature with either normal rabbit serum or anti HSV hyper immune serum (1:10,000) followed by three washes in cold PBS, pH 7.4 for 10 min each and further incubated with 1:20 dilution of fluoresceinated anti-rabbit serum (Dakopatts) absorbed with mouse spleen and liver acetone extracted powder (Sigma) at $100 \mathrm{mg} / \mathrm{ml}$ of neat sera, for $20 \mathrm{~min}$ at room temperature. The slides were washed three times in PBS, mounted in buffered glycerol (PBS pH 7.4 and glycerol in ratio of 1:1) and examined under a fluorescence microscope (Carl Zeiss, E. Germany).

\section{ELISA:}

$2 \mu \mathrm{g} /$ well antimouse immunoglobulin serum raised in rabbit was coated on to the polyvinyl immuno plates in carbonate-bicarbonate buffer, $\mathrm{pH} 9.5$, overnight at $4^{\circ} \mathrm{C}$. Nonspecific sites were blocked with $1 \% \mathrm{BSA}+0.5 \%$ NMS (normal mouse serum) in PBS, 7.4 for $30 \mathrm{~min}$ at room temperature, followed by washings for $3 \mathrm{~min}$ each in PBS $+0.025 \%$ Tween-20. $200 \mu \mathrm{l}$ supernatant from wells showing cell growth was added to each well and incubated at $37^{\circ} \mathrm{C}$ for $2 \mathrm{~h}$, followed by washing as mentioned earlier. Anti HSV-HRP conjugate was then added to the wells and further incubated at $37^{\circ} \mathrm{C}$ for $2 \mathrm{~h}$, followed again by washing. Substrate O-phenylene diamine (OPD) in acetate buffer, $\mathrm{pH}$ 5.0 was added to each well and left for color development in the dark at room temperature. The reaction was stopped by adding $25 \mu \mathrm{l}$ of $2 \mathrm{M} \mathrm{H}_{2} \mathrm{SO}_{4}$ and O.D. was read at $492 \mathrm{~nm}$ in the ELISA reader.

\section{Characterization of $A b-2$}

Solid phase RIA (Radio Immuno Assay): Ab-2 Binding Specificity:

Polyvinyl immunoplates were coated with monoclonal antibody 138 C5G10 (Ab-1) and also with a panel of 7 irrelevant monoclonal antibodies in PBS, pH 7.4 at $4^{\circ} \mathrm{C}$ for 18 h. Wells were then washed with PBS three times and blocked with PBS containing $1 \%$ BSA and $0.5 \%$ normal mouse serum for $30 \mathrm{~min}$ at room temperature followed again by washing with PBS containing .05\% Tween-20. 20,000 counts of each radioiodinated monoclonal Ab-2 were added in triplicate. The plates were left for incubation at $4^{\circ} \mathrm{C}$ for 
$4 \mathrm{~h}$. The wells were washed again and air dried. Individual wells were cut and gamma counted. Results were expressed as percentage binding. Binding to myeloma supernatant served as negative control.

Solid Phase RIA: Inhibition of Antigen Binding by Ab-2:

Polyvinyl immunoplates were coated with 138 C5G10 (Ab-1) and subsequently blocked and washed as described above. .1, 1, 10 and $100 \mathrm{ng}$ of Ab-2 was added in triplicate at $4^{\circ} \mathrm{C}$ for $1 \mathrm{~h}$. gB- 1 was affinity purified using $138 \mathrm{C} 5 \mathrm{G} 10$, radioidionated (Reddy et al., 1977) and 50,000 counts of radioiodinated immunoaffinity purified gB-1 (calculated as optimal binding activity with 138 C5G10) were also added. The positive control comprised the serum from the same animal that was immunized with 138 C5G10 to raise these Ab-2 clones. Normal mouse serum served as the negative control of inhibition. The result is seen as a decrease in cpm bound of radiolabelled $\mathrm{gB}-1$ with increase in $\mathrm{Ab}-2$ concentration. Inhibition of total binding was calculated as follows:

Total binding $=\frac{\text { Mean bound cpm }(\mathrm{Ab}-2 \text { combinations }) \times 100}{\text { Absolute binding }(\mathrm{gB}-1 *+\mathrm{NMS})}$

* Radiolabelled gB-1

Binding inhibition $(\%)=100-$ Total binding

Solid Phase RIA: Ab-2 Fine Specificity:

Polyvinyl immunoplates were coated, blocked and washed as described. Various combinations (Table 2) of fixed counts of radioiodinated and unlabelled Ab-2 (concentration of each Ab-2 which was capable of reducing the negative control radioactivity value in the antigen binding inhibition assay in half) were added in triplicate to 138 C5G10 coated wells. This was incubated for $4 \mathrm{~h}$ at $4{ }^{\circ} \mathrm{C}$, washed and air dried. Individual wells were cut and gamma counted.

\section{RESULTS AND DISCUSSION}

\section{Detection of $A b-2$}

Of 8 positive hybrids detected in immunofluorescence and ELISA, three clones $3 \mathrm{Ai}$ B5D10, 3Ai B3E10 and 3Ai B3C9 (Figure 1a, 1b and 1c and Figure 2) were stabilized. They showed good reactivity in ELISA and were also found to be secreting Ab-2 when the surface bound $\mathrm{Ab}-2$ was stained by anti-HSV hyperimmune sera in immunofluorescence. It is a possibility that Ab-2 is reacting with interspecies determinants which are not really a part of the actual combining site in molecular contact with HSV antigen but are essential for the construction of binding site of the right specificity (Thanavala et al., 1985b; Urbain et al., 1980; Ju et al., 1981). However, the negative controls consisting of staining of surface bound $\mathrm{Ab}-2$ with rabbit preimmune serum show no fluoresence with any of the three clones.

\section{Recognition of Paratope}

Specificity studies were done in solid phase RIA. Each Ab-2 was radioiodinated. Direct binding of radiolabelled Ab-2 to the idiotype 138 C5G 10 and 7 other irrelevant 


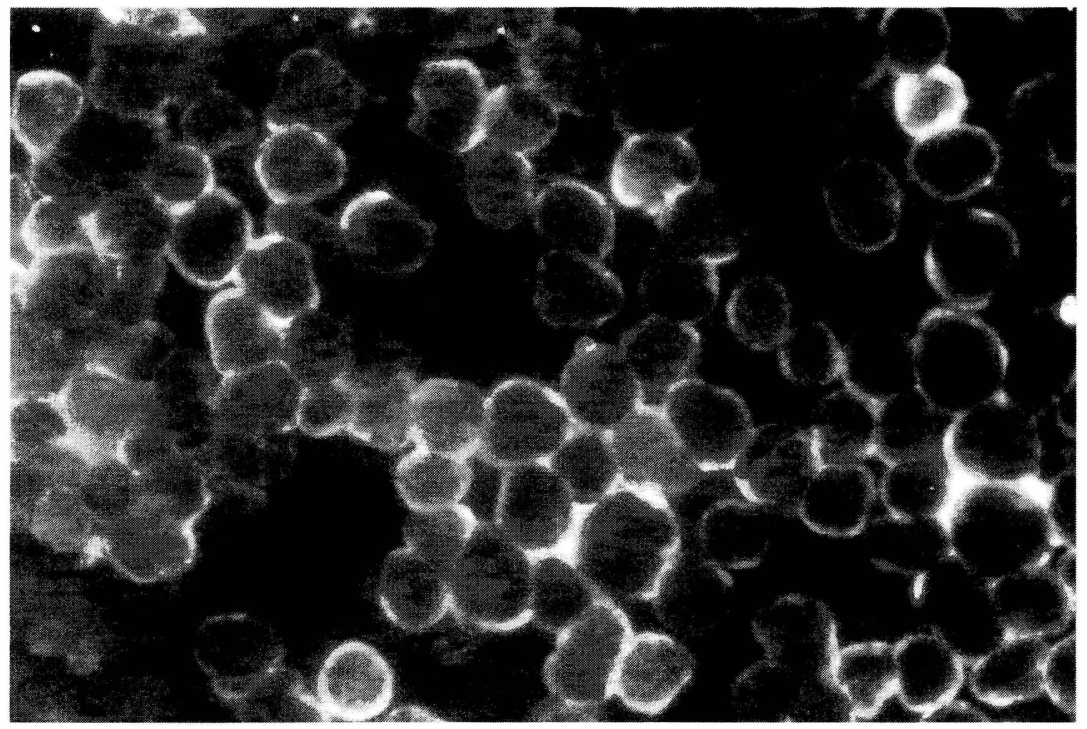

Fig. 1a

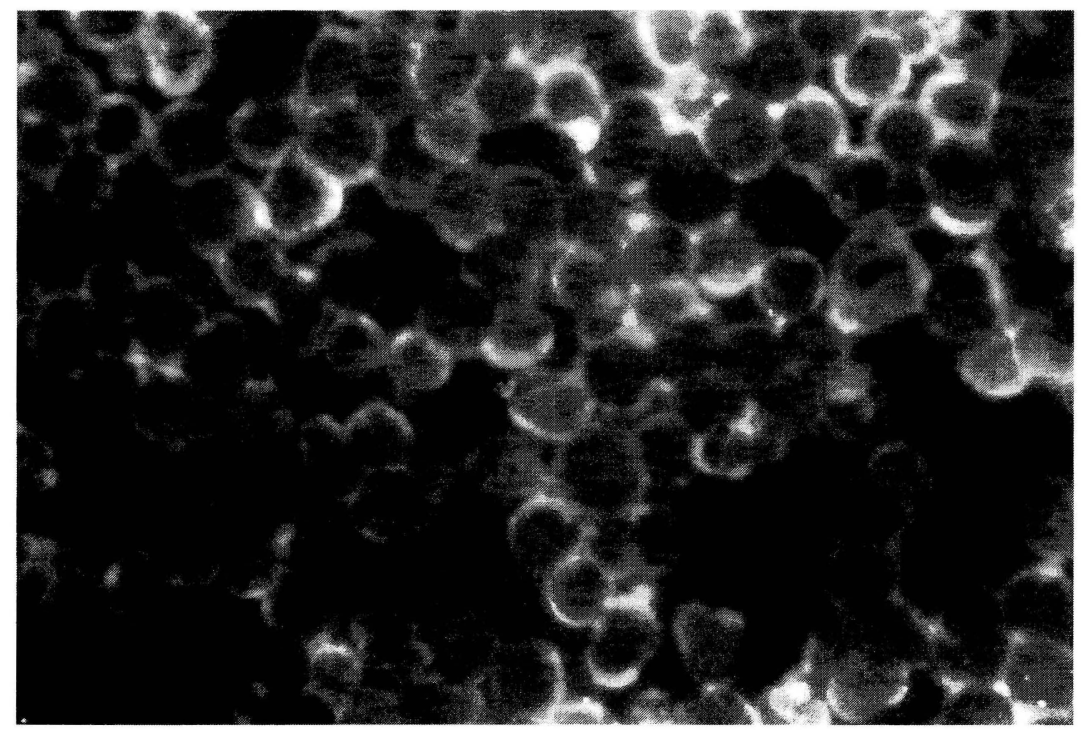

Fig. 1b 


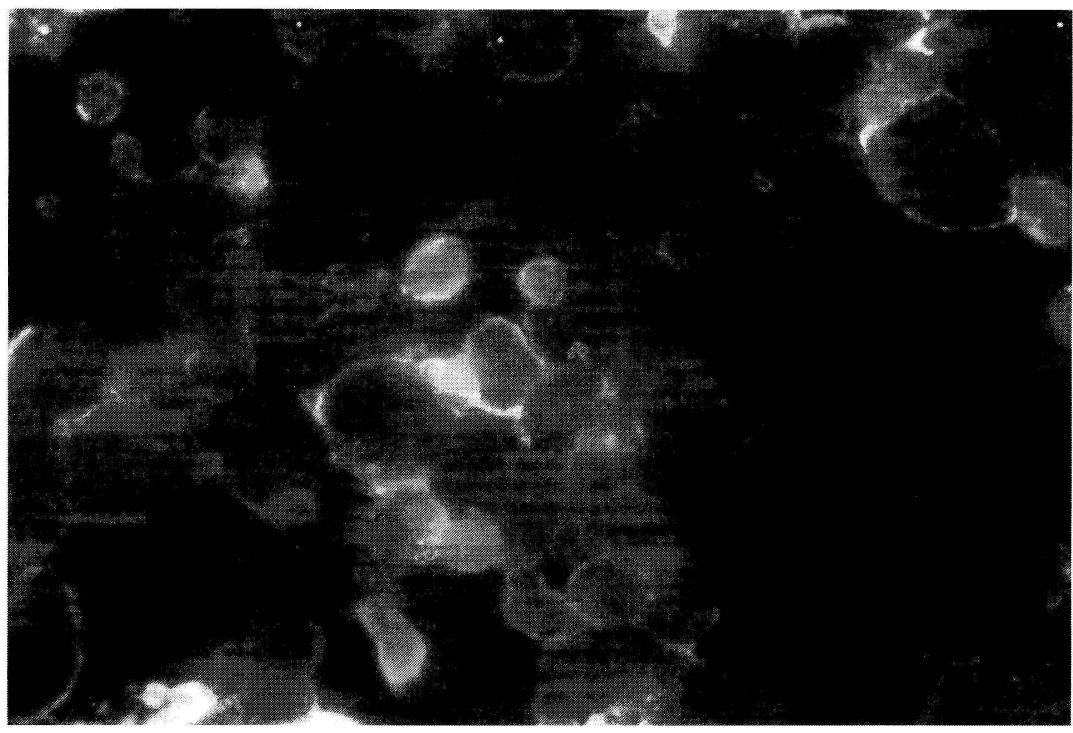

Fig. 1c

Fig. 1. Immunofluorescent staining of AB-2 producing clones. Photomicrographs $\mathrm{B}$ showing cytocentrifuge smears of clones (a) $3 \mathrm{Ai} \mathrm{B} 3 \mathrm{E} 10$ (b) 3 Ai B5C9 and (c) 3 Ai B5D10 were made. Surface bound Ab-2 was detected by staining with rabbit anti-HSV hyperimmune sera followed by fluoresceinated anti-rabbit serum.

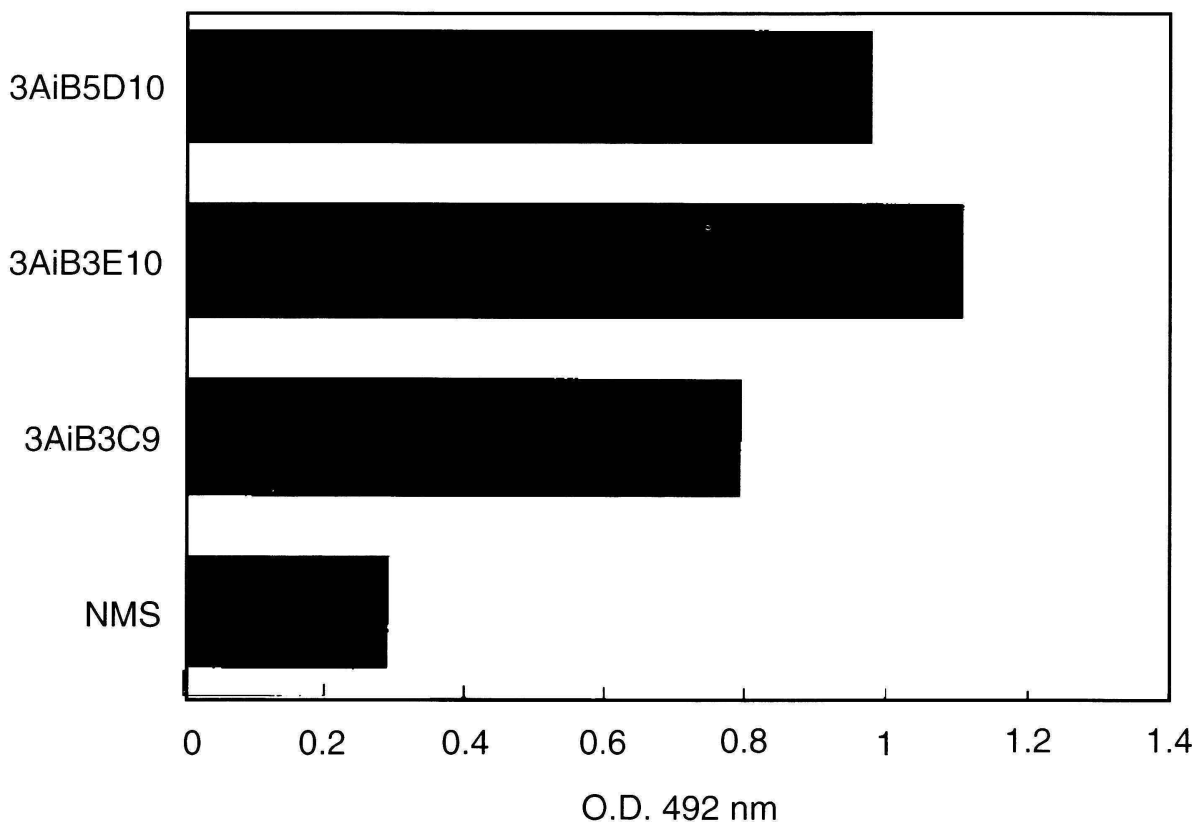

Fig. 2. Screening for Ab-2 by ELISA. Optical density values obtained using culture supernatants of the three monoclonal antibody secreting Ab-2 clones and normal mouse serum (NMS) to EIA plates coated with antimouse immunoglobulin serum., Bound specific Ab-2 was detected using anti HSV-HRP conjugate. 
monoclonal antibodies (Table 1) were studied. As seen in Figure 3, percentage binding of antibodies 3Ai B3E10 and 3Ai B5D10 to 138 C5G10 was $72.45 \%$ and $73.61 \%$ respectively. Whereas, the binding of these two $\mathrm{Ab}-2$ monoclonal antibodies to the panel of irrelevant antibodies range from $11.58 \%$ to $31.1 \%$ and $10.03 \%$ to $14.06 \%$ respectively. 3Ai B3C9 showed an altogether different binding pattern. The percentage of specific binding was $66.97 \%$. It varied from $10.26 \%$ to $47.7 \%$ with irrelevant idiotypes. K4 and the three other anti-HSV-1 monoclonal antibodies (137 C2C5, 137 C5F12 and 137 $\mathrm{C} 2 \mathrm{C} 8$ ) exhibit highest reactivity to $3 \mathrm{Ai} \mathrm{B} 3 \mathrm{C} 9$. The specificities of these four 'irrelevant' antibodies do not fall into any one category. $137 \mathrm{C} 2 \mathrm{C} 5$ and $137 \mathrm{C} 2 \mathrm{C} 8$ share specificities and compete with each other but not with $138 \mathrm{C} 5 \mathrm{G} 10$. On the other hand $137 \mathrm{C} 5 \mathrm{~F} 12$ reacts specifically to $\mathrm{gE}-1$, while the specificity of $\mathrm{K} 4$ is unknown although it is certain that the antibody was not raised against either HSV-1 or HSV-2. The only common feature is that all of them are of murine origin. This suggests that 3Ai B3C9 may be identifying a region which is very close to the binding site of $138 \mathrm{C} 5 \mathrm{G} 10$ and which is not unique to it but is shared by other related and unrelated mouse monoclonal antibodies. The concept of internal image does not imply that the Ab-2 molecules carry a structure resembling the entire antigenic site. Thus, an individual Ab-2 beta molecule would react only with those antibodies that use a particular set of contact residues to bind to the antigen. Since all Ab-2 that are induced are unlikely to be Ab-2 beta type but include antibodies directed against a framework idiotype of Ab- 1 that tends to be found in association with paratopes of a particular specificity (Roitt et al., 1986).

Table 1. Specificities of Panel of Monoclonal Antibodies used for Testing Ab-2 Specifity

\begin{tabular}{lll}
\hline & \multicolumn{1}{c}{ Antibody } & \multicolumn{2}{l}{ Specificity } \\
\hline 1. & 138 C5G10 & HSV-1 (gB-1) \\
2. & 137 C2C5 & HSV-1 (gB-1) \\
3. & 137 C5F12 & HSV-1 (gE-1) \\
4. & 137 C2C8 & HSV-1 (gB-1) \\
5. & BB & HSV-2 \\
6. & K1 & Unknown \\
7. & K4 & Unknown \\
8. & K8 & Unknown \\
9. & Myeloma & Unknown \\
\hline
\end{tabular}

\section{Ab-2 mimics epitope of antigen}

To determine whether all the three $\mathrm{Ab}-2$ bore the internal image of the original $\mathrm{gB}$ 1, their ability to block binding of radiolabelled antigen to $138 \mathrm{C} 5 \mathrm{G} 10$ was examined (Figure 4). 3Ai B5D10 and 3Ai B3E10 were able to inhibit the binding of radioiodinated gB-1. However, 3Ai B3C9 was less efficient in this assay. 3Ai B5D10 and 3Ai B3E10 reduced the radioiodinated antigen binding to $18.02 \%$ and $21.97 \%$ respectively while $3 \mathrm{Ai} \mathrm{B} 3 \mathrm{C} 9$ reduced the binding to nearly $30 \%$. This demonstrates that these Ab-2 were not only reacting with the paratope of $138 \mathrm{C} 5 \mathrm{G} 10$ but may also be mimicking an epitope found on $\mathrm{gB}-1$. Therefore, these Ab-2 inhibited the subsequent reaction of $138 \mathrm{C} 5 \mathrm{G} 10$ 
$\%$ lodine bound

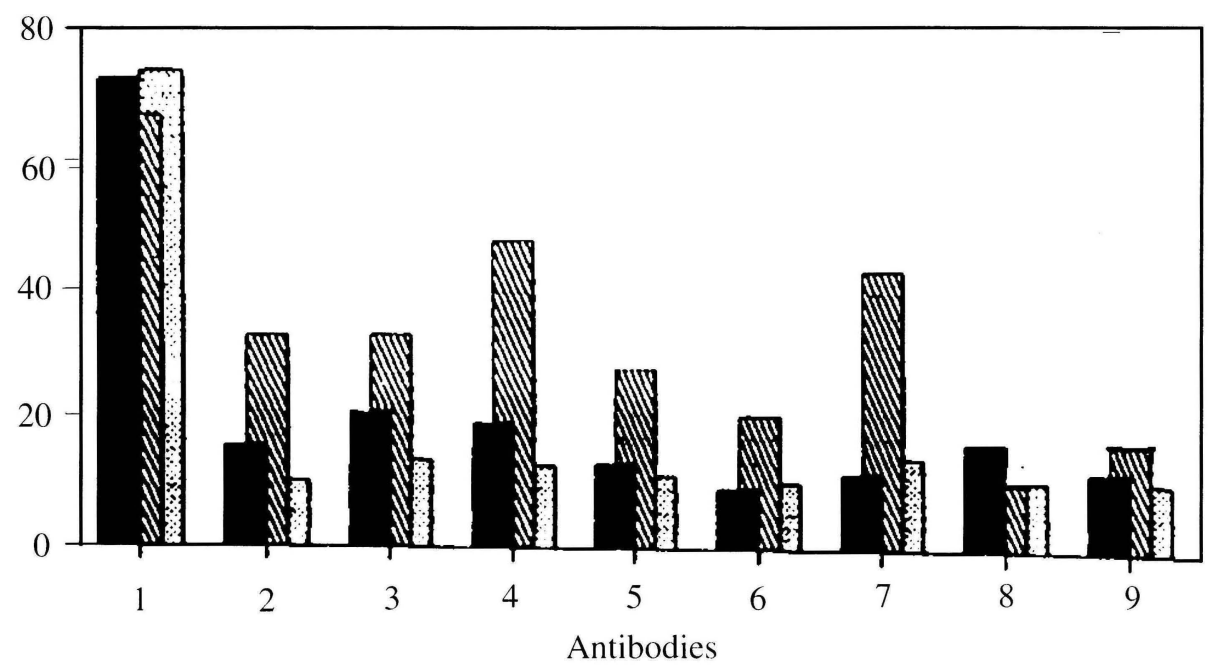

3AiB3E1 Allll 3AiB3C9 \$3AB5D10

Fig. 3. RIA for Ab-2 specificity. Antibodies 1, 2, 3, 4, 5, 6, 7, 8, and 9 denote antibodies 138 C5G 10,137 $\mathrm{C} 2 \mathrm{C} 7,137 \mathrm{C} 5 \mathrm{~F} 12,138 \mathrm{C} 2 \mathrm{C} 8, \mathrm{~B} 3, \mathrm{~K} 1, \mathrm{~K} 4, \mathrm{~K} 18$ and Myeloma supernatant respectively which were used for coating microwells. To these was added 20,000 counts of ${ }^{125}$ I labelled Ab-2 in triplicate. Readings are represented as an average mean.

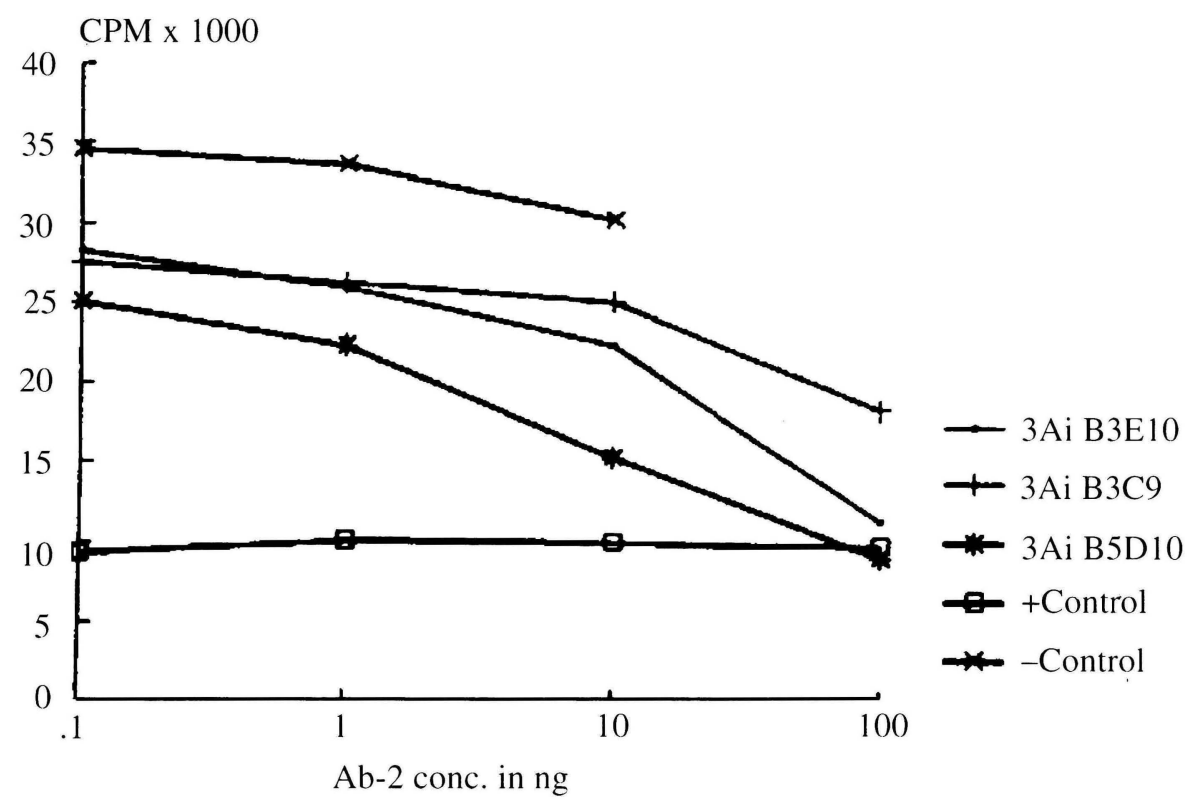

Fig. 4. Blocking of antigen binding by Ab-2 in RIA. Binding curves of $\mathrm{Ab}-1$ to $\mathrm{Ab}-2$, mouse hyperimmune serum and normal mouse serum. 
with antigen. Hence, both Ab-2 and gB-1 bind to the same paratope of $138 \mathrm{C} 5 \mathrm{G} 10$ or a region very close to the paratope.

\section{Fine specificity of $A b-2$}

Fine specifities of binding of Ab-2 to $138 \mathrm{C} 5 \mathrm{G} 10$ were determined by putting combinations of $\mathrm{Ab}-2$, one radiolabelled and the other not radiolabelled, in competition. Table 2 shows that $3 \mathrm{Ai}$ B3E10 and 3Ai B5D10 inhibited the binding of each other to 138 C5G10. 3Ai B3E 10 inhibited total binding of radioiodinated 3Ai B5D10 by $66.8 \%$ and $3 \mathrm{Ai}$ B5D 10 inhibited the total binding of radioiodinated $3 \mathrm{Ai} \mathrm{B} 3 \mathrm{E} 10$ by $83.2 \%$. On the other hand $3 \mathrm{Ai}$ B $3 \mathrm{C} 9$ inhibited the total binding of $3 \mathrm{Ai} \mathrm{B} 3 \mathrm{E} 10$ by $30.9 \%$ and that of $3 \mathrm{Ai}$ B5D 10 by $5 \%$. This suggests that $3 \mathrm{Ai}$ B3E10 and 3Ai B5D 10 shared the same unique fine specificity while $3 \mathrm{Ai}$ B3C9 shares a different specificity on 138 C5G10 paratope.

Table 2. Fine Specificity of Binding of Ab-2

\begin{tabular}{lccc}
\hline $\begin{array}{c}\text { Combinations } \\
\text { of Ab-2 }\end{array}$ & Counts added & $\begin{array}{c}\text { Mean }{ }^{125} \mathrm{I} \\
\text { bound } \\
(\mathrm{cpm})\end{array}$ & $\begin{array}{c}\text { Total binding } \\
\text { inhibition } \\
(\%)\end{array}$ \\
\hline $1^{*+2}$ & 20,000 & 9920 & 30.9 \\
$1^{*+3}$ & 20,000 & 2418 & 83.2 \\
$2^{*}+1$ & 20,000 & 3607 & 65.82 \\
$2^{*+3}$ & 20,000 & 2042 & 80.71 \\
$3^{*}+1$ & 20,000 & 4562 & 66.81 \\
$3^{*}+2$ & 20,000 & 13049 & 5.05 \\
$1^{*+N M S}$ & 20,000 & 14355 & \\
$2^{*}+\mathrm{NMS}$ & 20,000 & 10551 & \\
$3^{*+\mathrm{NMS}}$ & 20,000 & 13743 & \\
\hline
\end{tabular}

i) $1 *, 2 *$ and $3 *$ represent radiolabelled $\mathrm{Ab}-2$ antibodies $3 \mathrm{AiB} 3 \mathrm{E} 10,3 \mathrm{AiB} 3 \mathrm{C} 9$ and $3 \mathrm{AiB} 5 \mathrm{D} 10$ respectively.

ii) 1, 2 and 3 represent unlabelled Ab-2 antibodies 3AiB3E10 and 3AiB3C9 and 3AiB5D10 respectively.

The diagnostic value of serological assays is limited by multiple antigens shared by HSV-1 and HSV-2. There may also be some heterotypic anamnestic responses to varicella-zoster virus in persons infected with HSV and vice versa. Added to this, the purification of specific antigens of HSV-1 or HSV-2 is a tedious process. With the use of anti-idiotype that represents a specific antigen of HSV-1 or HSV-2 and its role in trapping type specific antibodies the serological assays will be more meaningful.

It has been shown in many systems that anti-idiotypic reagents that mimic epitopes on appropriate antigens can be substituted for antigen-specific immune response in vivo (Kennedy and Dreesman, 1985). Modulation of Herpes simplex virus infection is of great interest (Kennedy et al., 1984; Gell and Moss, 1985; Lathey et al., 1986). Kennedy and his group (Kennedy et al., 1984) reported that polyclonal anti-idiotype reagents increased the pathogenicity of HSV-2 infection on challenge after anti-idiotype administration. In contrast to this, another study (Gell and Moss, 1985) reports that polyclonal 
rabbit anti-idiotypes could generate dose dependent delayed type hypersensitivity responses when mice were challenged with HSV-1 subcutaneously in the ear pinna after prior administration of anti-idiotype serum. Immunization of mice with anti-idiotype to glycoprotein D of HSV was seen to prime mouse splenocytes in vivo to proliferate in response to HSV antigen stimulation in vitro (Lathey et al., 1986).

The paratope-idiotypic interactions between $\mathrm{B}$ cells and regulatory $\mathrm{T}$ cells, have a physiological regulatory effect. There exist regulatory $\mathrm{T}$ cell counterparts for Ab-1 and Ab-2 antibodies (Bona, 1981). Therefore, we are now in the process of testing the functional efficacy of our Ab-2 and their role in inducing cell mediated immunity. We have tried to assess the antigen specific priming ability of the Ab-2 antibodies by immunizing mice with various doses of each $\mathrm{Ab}-2$ in different sets and subsequently stimulating the T cells with affinity purified gB-1 antigen in culture. Preliminary results show that two out of three Ab-2, 3Ai B3E10 and 3Ai B5D 10 are able to prime the mouse $\mathrm{T}$ cells in vivo. These Ab-2 primed cells were able to recognise the in vitro stimulation signal of the antigen $\mathrm{gB}-1$ and were consequently seen to proliferate as assessed by incorporation of tritium labelled thymidine from the culture medium. The stimulation indices obtained were comparable to those obtained in the positive control for proliferation where the mice $T$ cells were both primed and stimulated with affinity purified gB1 at optimally calculated doses. This pilot study reveals a very interesting aspect of the characteristics of these $\mathrm{Ab}-2$ which has importance in determining their value as surrogate antigens in the construction of subunit vaccine.

\section{REFERENCES}

Bernstein, M.T. and Stewart, J.A. (1971). Method of typing antisera to herpes virus hominis by indirect hemagglutination inhibition. Appl. Microbiol., 21, 680-684.

Bona, C.A. (1981). Idiotypes and Lymphocytes. New York: Academic Press.

Dreesman, G.R and Kennedy, R.C. (1985). Anti-idiotypic antibodies: Implications of internal image based vaccines for infectious diseases. J. Infect. Dis., 5, 761-765.

Figueroa, M.E. and Rawls, W.E. (1969). Biological markers for differentiation of herpes virus strains of oral and genital origin. J. Gen. Virol., 4, 259-267.

Frame, B., Mahony, J.B., Balachandran, N., Rawls, W.E. and Chernesky, M.A. (1984). Identification and typing of herpes simplex virus by enzyme immunoassay with monoclonal antibodies. J. Clin. Microbiol., 20, 162-166.

Gell, P.G.H. and Moss, P.A.H. (1985). Production of cell-mediated immune response to herpes simplex virus by immunization with anti-idiotypic heteroantisera. J. Gen. Virol., 66, 1801-1804.

Gupta, P.C., Seth, P., Banerji, A.K., Gupta, P.K. and Roy, S. (1972). Herpes simplex encephalitis. Neurology (India), 20, 136-141.

Ju, S.T., Pierres, M., Germain, R., Benaceraff, B. and Dorf, M.E. (1981). Idiotypic analysis of anti GAT antibodies. VIII Comparison of interstain and allotype associated idiotypic specificities. J. Immunol., 126, 177-182.

Kennedy, R.C., Adler-Storthz, K.and Burns, S.R. (1984). Anti-idiotype modulation of herpes simplex virus infection leading to increased pathogenicity. J. Virol., 50, 951-953.

Kennedy, R.C. and Dreesman, G.R. (1985). Immunoglobulin idiotypes: analysis of viral antigenantibody systems. Prog. Med. Virol., 13, 168-177.

Kohler, G. and Milstein, C. (1975). Continuous cultures of fused cells secreting antibody of predefined specificity. Nature (London), 256, 495-497. 
Lathey, J.L., Rouse, B.T. and Wiley, D.E. (1986). Production and characterization of antiidiotypic antibody specific for a monoclonal antibody to glycoprotein D of herpes simplex virus. Immunology, 57, 29-35.

Lennette, E.H. and Smith, N.J. (1979). Diagnostic procedures for viral, Rickettsial and chlamydial infections. 89.

Pereira, L., Klassen, T. and Baringer, R.J. (1980). Type- common and type- specific monoclonal antibody to herpes simplex virus type 1. Infec. Immun. 29, 724-732.

Prakash, S.S. and Seth, P. (1979). Evaluation of indirect hemagglutination and its inhibition in differentiation between antibodies to herpes simplex virus types 1 and 2 for seroepidemiological studies: Use of alI/I index threshold of 85 as an assay of type specific antibodies. J. Inf. Dis., 139, 524-528.

Reddy, P.K., Devare, S.G., Vasudev, R. and Sharma, P.S. (1977). Simplified radioimmunoassay for viral antigens. J. Natl. Can. Inst., 58, 1859-6.

Roitt, I.M., Branstoff, J. and Male, D.K. (1986). Idiotypic regulation. In: Immunology: Gower Medical Publishing Ltd., 10, 3-10.7.

Seth, P., Prakash, S.S. and Kesavalu, L. (1978). Indirect hemagglutination test in typing herpes simplex virus and antibodies. Ind. J. Med. Res., 68, 887-895.

Seth, P., Rawls, W.E., Duff, R., Rapp, F., Adam, E. and Melnick, J.L. (1974). Antigenic differences between isolates of herpes virus 2. Intervirology; 3, 1-4.

Thanavala, Y.M., Bond, A., Hay, F.C. and Roitt, I.M. (1985a). Immunofluorescent technique for the detection of monoclonal internal image anti-idiotypic antibodies to HBs antigen. J. Immun. Methods, 83, 227-232.

Thanavala, Y.M., Bond, A., Tedder, R., Hay, F.C. and Roitt, I.M. (1985b). Monoclonal internal image anti-idiotypic antibodies of Hepatitis B surface antigen. Immunology, 55, 197-204.

Urbain, J., Cazenave, P.A., Wikler, M., Franssen, J.D. et al. (1980). Idiotypic induction and immune networks. In: Fourgereau, M. and Dansset, J (Eds). Progress in Immunology IV. New York: Academic Press, 81. 


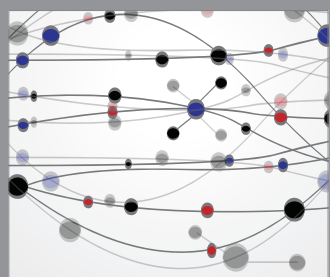

The Scientific World Journal
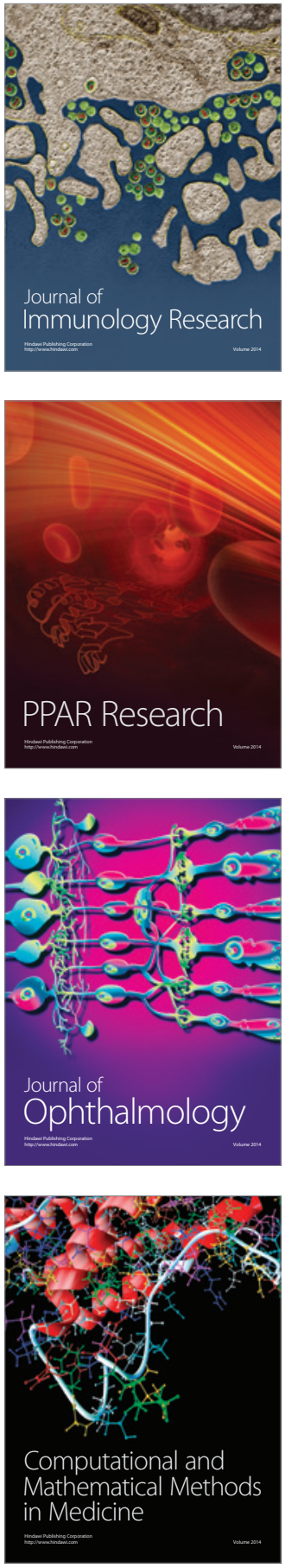

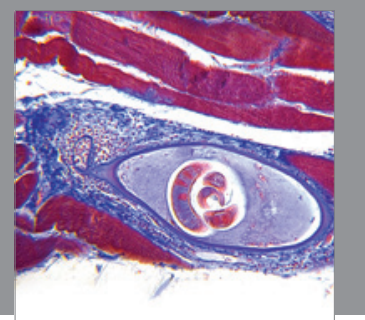

Gastroenterology

Research and Practice
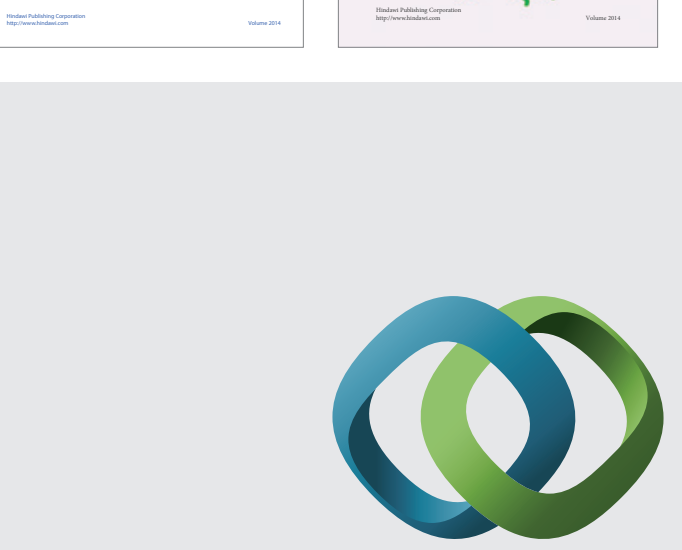

\section{Hindawi}

Submit your manuscripts at

http://www.hindawi.com
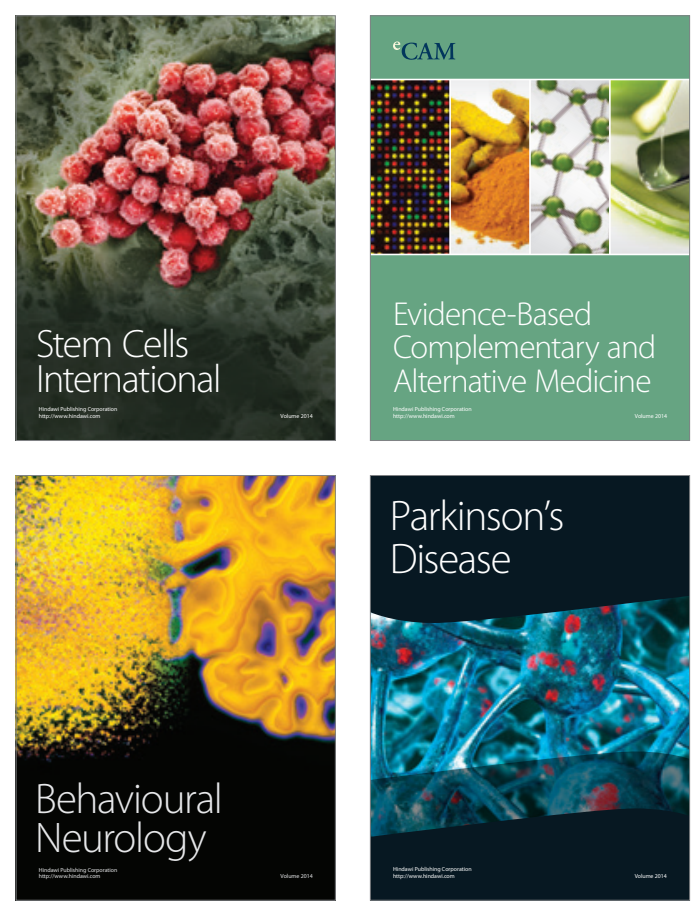

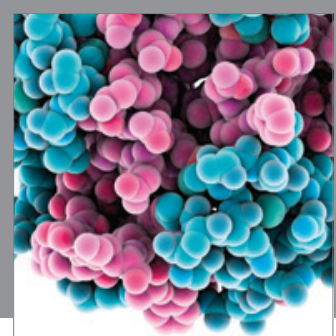

Journal of
Diabetes Research

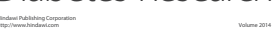

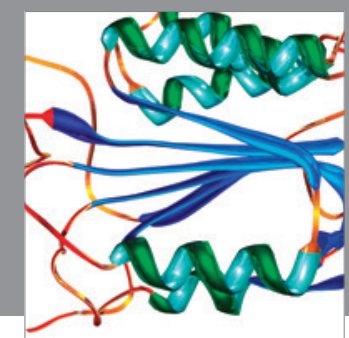

Disease Markers
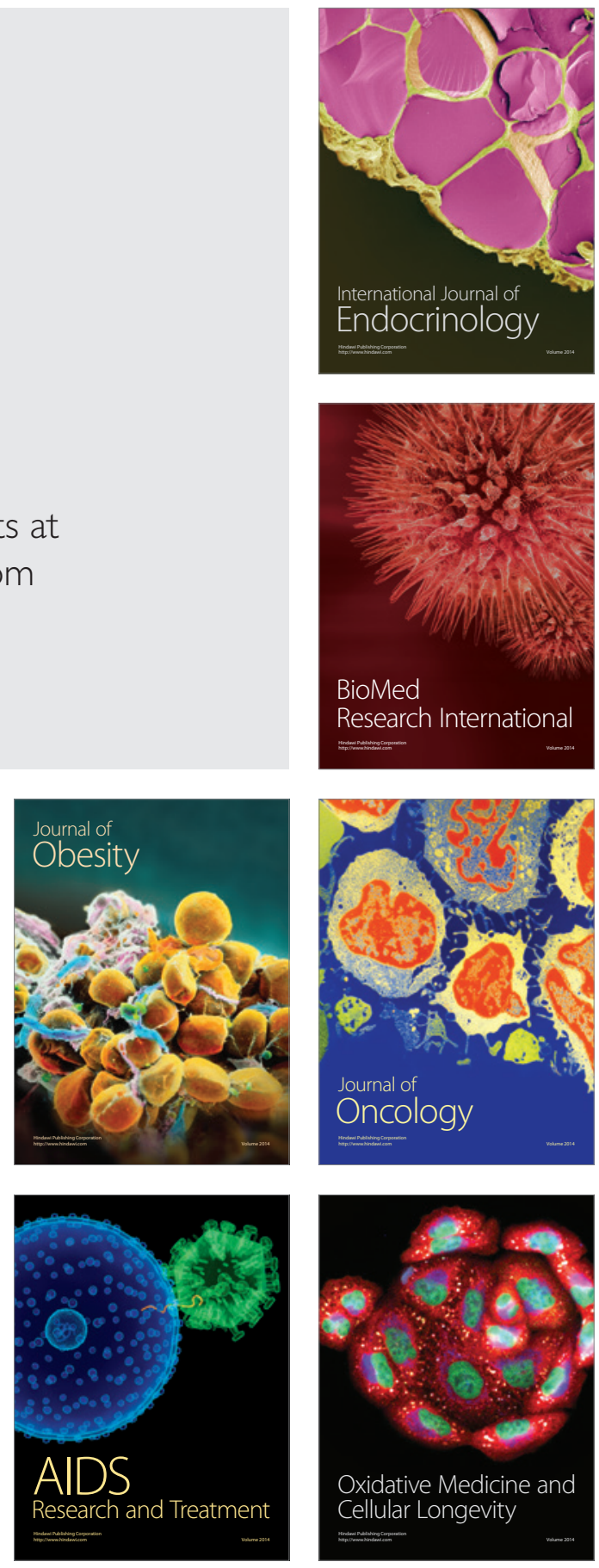